\title{
P-23 TECTONIC SETTING AND HYDROCARBON PROSPECTS PROBLEMS OF THE WESTERN ALBANIA
}

ENGJELL PRENJASI, FATMIR FEZGA and VILSON BARE

Oil and Gas Institute, Fier, Albania

Three following tectonic units are the main integral parts of the Western Albania.

1) Sazani zone or Pre-Apulian platform represents a big monocline composed of the Cretaceous carbonates that dips gradually northeastwards under Albania Thrust Belt.

2) Albania Thrust Belt represents a tectonic assemblage composed of several tectonic zones that lie southeast-northwestwards in direct northern continuation of the Hellenides.

The Thrust Belt consists of four rocky formations as follow:

a) The Carbonate formation ranges from the Upper Triassic to the Eocene age. They sometimes are interrupted by the evaporitc rocks of the Upper Triassic age that have emerged from their normal position owing to a common effect of tectonic forces and diapirism phenomenon.

b) The Flysch formation of the Oligocene age that often increases considerably its thickness, due to a very complex common effect of lithological changes, tectonic folding and clay diapirism. (E. Prenjasi, 1991, 1997)

c) The Flyschoid formation of the Upper Oligocene - Lower Miocene age, that consists chiefly of thick bedded intercalations of sandstone, puddings, silts and clays.

d) The Premolasses formation of the age of the Burdigalian - Tortonian included, that consists chiefly of massive marls and marly clays with intercalation of lithothamnium sandy limestone.

The three first formations set up the Lower Tectonic Stage of the Albania Thrust Belt. While the Premolasses deposits of the Burdigalian - Tortonian age set up the Middle Tectonic Stage. (K. Plaku 1962; H. Dalipi 1987)

3) Durresi Basin is an integral part of the Peri Adriatic Foredeep. It is filled up with molasses deposits of the Messinian and the late molasses of the Pliocene that set up the Upper Tectonic Stage and lie unconformably on both the Platform and the Thrust Belt. Nevertheless, the Neogene structures of the Durresi basin more or less must have inherited the form of the anticline structures of the Lower Tectonic Stage. Sometimes the unconformity between the tectonic stages becomes gradually invisible. (H. Bakia, 1987)

Thrusting of the Albania thrust belt, as well as of the Western Hellenic Napes (Jacobshagen 1987) onto the Pre-Apulian platform has created some serious difficulties in respect of obtaining seismic information on the structural and tectonic features of eastwards platform dip. Therefore, for the time being, it is very difficult to connect and interpret the rare complex data under the Frontal thrust plane.

The thrust phenomenon is obvious at the outcrop area of these tectonic units in southwestern Albania. Father north the trace of the thrust is completely masked under molasses 
deposits of the Durresi basin. Nevertheless, it's possible to depict the spatial position of the Frontal thrust plane.

The seismic survey data and the data of many drilled wells suggest that the lonian zone represents the western edge of the Thrust Belt. This zone consists of several anticline lines or chains separated by the relevant syncline lines.

All the structural lines of the Thrust Belt lie northwestwards up to their progressive interruption against the Frontal thrust.

The three above mentioned tectonic units of the Western Albania have significant interest for oil exploration as follow:

The first trend of the spatial location of the hydrocarbon prospects belongs to the anticline lines of the Thrust Belt. Each anticline line consists of several eroded anticlines and anticline carbonate structures overlain by flysch. The latter, often are masked by transgressive molasses deposits or by the thrust of the eroded structures. (E. Prenjasi 1991)

Existence of steep flanks and extensional closures in most of the anticline carbonate structures overlain by folded flysch, often have created big problems for seismic survey. The same acquisition method applied in the Sazani zone has turned out no effective in the Thrust Belt territory. Therefore, it has not been possible to record the top Eocene level of the carbonate structures overlain by flysch in the thrust belt part of Albania's Southern Offshore. Nevertheless, depiction of the geological setting and carbonate oil prospects of this offshore part (Fig. 9 Western and Eastern Sasaj), could be possible owing to complex interpretation of several detailed geological data observed along the coastline area, as well as some relatively poor data of few onshore seismic lines. That's why, it is planed to cooperate with foreign companies for. tackling some methodical seismic lines in order to increase the ratio signal / noise.

On the other hand, prognosticating of the oil-bearing sandstone beds in molasses deposits of Miocene and Pliocene age (Fig. 9 C, Sasaj bay) are based on good quality data of offshore seismic survey. However, it is still very necessary for further investigations on the existence of the longitudinal closure of this bay.

Another obstacle in respect of obtaining seismic information is the existence of many local thrusts, often of considerable horizontal amplitude, within the Thrust Belt, and especially along its frontal thrust. In these occurrences, the top Eocene limestone boundary is not recorded as usually in a form of a two or a three-phase horizon associated with transparent facies above and under the horizon. Although, substantial acquisition improvements are achieved due to fold increase up to $48 \%$, charge hole depth of $30 \mathrm{~m}$, charge size of $5-7 \mathrm{~kg}$ and the short trace interval of $25 \mathrm{~m}$ instead of $50 \mathrm{~m}$. Additionally, it is required further integration of both exploratory methods Geology and Seismic through Iterative Modeling Approach.

On the other hand, the possible direct contacts between the limestone of the Sazani zone and the limestone of the thrust belt along the frontal thrust plane might have brought about the depleting of the former traps. Presumably, aggressive activity of the movement of the underground waters has caused a potential impact on the oil accumulations within this tectonic setting framework. So, very low salinity waters are obtained from two wells that have penetrated the limestone of one prospect, respectively at about 4500 and $480 \mathrm{Om}$.

The depth of the oil fields and oil prospects within the Thrust Belt ranges from about 100 $\mathrm{m}$ to below $5000 \mathrm{~m}$.

The second trend of the spatial spread of the hydrocarbon prospects in the Western Albania belongs to the Sazani zone.

There are several carbonate structures and erosion mounts overlain transgressively by premolasses or molasses deposits of the Neogene series of Burdigalian to the Pliocene age 
included. Surely, this type of prospect is threatened by possible direct contact between the eroded limestone and the sandstone beds above as it's encountered in one dry well drilled on a spectacular erosional carbonate mount, in offshore. Consequently, only little residual oil resulted in the carbonates of the well's bottom hole

Thirdly, there are some gas prospects located within the Durresi depression.

The seismic surveys carried out in the Durresi depression has resulted in solving some structural problems, as well as in partial solution of the chronological order of the tectonic faults and of seismic stratigraphy.

Also there are applied seismic procedures of sequence analyze for making out deposition sequences on the bases of reflection terminations. While the lithological changes within a seismic sequence are interpreted through the facies analyses, considering both the apparent forms of the reflections and their characteristics.

Albanian Explorationists, considering carefully all the seismic achievements in question, times after time have discovered several gas fields and gas leeks in the Neogene anticline structures of the Upper Tectonic Stage. On the contrary, some non-accurate depictions of the distribution of sandstone beds, tectonic features and the abnormal pressures phenomena within the Durresi basin have brought about some dry wildcats and developed wells.

In conclusion, despite the above-mentioned problems, all the oil and gas prospects made out in the Western Albania so far need further serious attention.

Firstly, it is necessary to realize an exact depiction of spatial structural position for all structural elements of each hydrocarbon prospect separately.

Secondly, it is necessary to make out and clarify, as well as possible, the presence of anyone from the above-mentioned troubles.

It is to be hoped, that we will achieve better results, if apply programs of direct exploration for hydrocarbons, that might be realized through the StratWorks and the other programs of Landmark company.

\section{References (Written in Albanian)}

1.-.K. Plaku; Sh. Hoxha 1962. Geological Setting, and Oil gas-bearing Perspective of the "Gorisht-Cakran-Ballsh" Region. (Geological survey report)

2 - H. Bakia; L. Thomai.1976 Geological Setting, and Oil gas-bearing Perspective of the "Cakrani" Region. (Geological survey report)

3- H. Bakia; D. Yzeiri; H. Dalipi; I. Dhimulla, 1987 Geological Setting and Oil gasbearing Perspective of the Kruja, Ionian, Sazani zones and Peri-adriatic Depression.

4 - Jacobshagen; Durr S, E; Kockel F; Koop O.K; Kovolozyk G., 1987 Structures and Geodynamic Evolution of the "Aegean" Region. (Written in English and German)

5 - E. Prenjasi, 1991. Tectonic Style and Present Spatial Position of the Carbonate Structures Overlain by Flysch in the Ionian Zone. (Doctor Dissertation)

6- E. Prenjasi, 1997 Geological Setting, and Oil gas-bearing Perspective of the "Perati" Region. (Complex Geo-seismic Synthesis) 


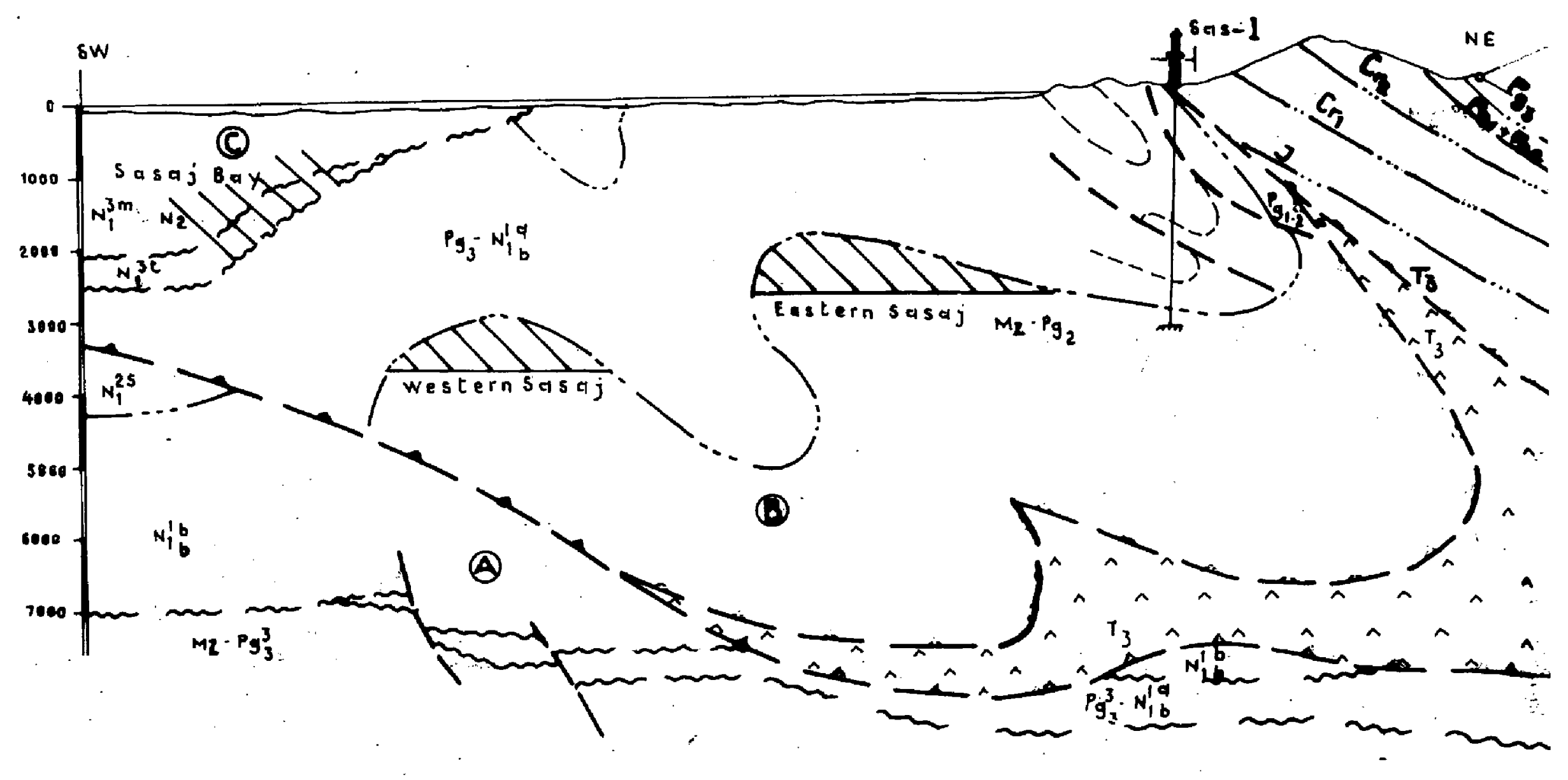

Fig. 9 Cross geoseismic profile IV- IV (254/81). Carbonate oil prospects in Albania thrust belt (B. Eastern and Western Sasaj) and sandstone oil prospect in Molasses deposits of Peri- Adriatic Foredeep (C. Sasaj Bay). Platform (A), Pliocene $\left(\mathrm{N}_{2}\right)$, Messinian $\left(\mathrm{N}_{1}{ }^{3 \mathrm{~m}}\right)$, Tortonian $\left(\mathrm{N}_{1}{ }^{3 t}\right)$,

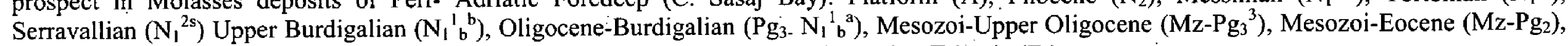
Paleocene + Eocene $\left(\mathrm{Pg}_{1}+\mathrm{Pg}_{2}\right)$, Upper/ Lower Cretaceous $\left(\mathrm{Cr}_{2} / \mathrm{Cr}_{1}\right)$, Jurassic (J), Upper Triassic $\left(\mathrm{T}_{3}\right)$. 